Hence, it violates neither the purpose nor the legal concept of non-recognition for a non-recognizing government to engage in that conduct which might ordinarily imply recognition, if an express statement of non-recognition has been issued.

It follows that the conduct of the United States mentioned at the beginning of this comment does not show that the United States has ceased to pursue a policy of non-recognition. ${ }^{56}$ On the contrary, it has done so consistently. In determining whether it should continue to do so, the limited potentialities of non-recognition must be taken into account. The United States may decide to continue to deny recognition to conquering nations-by declarations of refusal to recognize-in the hope that as a result aggression may one day be outlawed by the international community. With the limitations of non-recognition in mind, it can deny recognition and yet be free to prosecute its foreign policy unhampered by the inhibitions which a sanctionary view of non-recognition entails.

${ }^{E 8}$ The three instances of questionable conduct mentioned above are not inconsistent with non-recognition.

(a) The non-recognition policy of the United States toward conquests was well known in 1939; hence, the extradition treaty with Germany could not have implied recognition of the conquest of Austria, although the United States did not issue an express statement of non-recognition until later. Some difficulty could have been avoided had the declaration been made earlier. The case of United States ex rel. Zdunic v. Uhl, 46 F. Supp. 688 (1942), rehearing denied 47 F. Supp. 520 (1942), rev'd and remanded 137 F. 2d 858 (C.A. 2d, 1943), rehearing 56 F. Supp. 403 (1943), aff'd, rehearing denied 144 F. 2d 286 (C.A. 2d, 1944), illustrates the confusion arising from the court's efforts to ascertain whether we had implied recognition of Germany's conquest of Austria.

(b) In view of our non-recognition policy our dealings with the Soviet Union could not imply recognition of their legal control of Latvia. Yet the United States could have argued in the dispute that it did not recognize that the Soviets had any right to be in Latvia and, hence, that they had no right to order our plane to land or to shoot at our plane in an effort to protect Latvia. Our failure to make that defense did not destroy our non-recognition, but perhaps it indicated the practical significance the State Department attached to the non-recognition policy.

(c) The announcement that our meeting with the Chinese Communist government was not to imply recognition vitiated any possibility of recognition.

\title{
PERMISSIBLE EMPLOYEE DISLOYALTY AND THE DUANE JONES CASE
}

An employee's loyalty to his firm during the term of his employment is expected as a matter of course. Often, however, an employee desires to change positions or to enter business for himself, and while still employed he may be making detailed plans toward that end.

Caught between the desirability of free competition and the protection of a vested interest, the law has taken a middle ground. At no time may the 
employee interfere with the employer's contractual relationships. ${ }^{1}$ Nor may he divert the employer's present opportunities or profits while still employed.2 In some situations, however, certain elements of "good will"3 such as future business of customers, future service of employees, lease renewals, or other future expectancies arising out of prior satisfactory relationships, may legitimately be the subject of appropriation. Generally, an appropriation of such intangibles subsequent to the termination of employment is unobjectionable: ${ }^{4}$ this is free competition.

The law, however, is unclear where the appropriation occurs before the employment relationship has terminated. Certainly an employee planning to embark on his own venture is allowed to make preparation which may result in a diversion when he later enters into competition. As early as 1799, Lord Kenyon in Nichol v. Martyn stated that an employee may "endeavor to conciliate the regard of his master's customers, and to recommend himself to them. ..."s No case, however, has clearly delimited the extent of allowable preparation. The recent case of Duane Jones Co. v. Burke $e^{6}$ again raises this question.

The Duane Jones Co., formerly a highly successful advertising firm, had suffered serious business reversals. Duane Jones, sole owner and former president and chairman of the board, had apparently been guilty of "certain behavorial lapses" while conducting the firm's operations, ${ }^{7}$ and its business was declining rapidly. During the first six months of 1951 , the company had lost billings approximating $\$ 6,500,000$ out of a total of $\$ 15,500,000$, and several executives and staff members had resigned. A number of the firm's officers and directors had described conditions as "intolerable," and on June 18, 1951, the employees met to consider the problem. Mr. Scheideler, a director and officer, informed the group that he had "spoken to several of [the firm's] customers" and had gained a "favorable" reaction to a proposal that the group either buy out Duane Jones's interest or form a new corporation. Scheideler also suggested to the others "that they inquire whether the accounts being serviced by them ... would favor such a project."s

${ }^{2}$ Prosser, Torts 976-96 (1941).

2 E.g., Boston Deep Sea Fishing \& Ice Co. v. Ansell, 39 Ch. D. 339 (1888); consult note, 39 Col. L. Rev. 219 (1939).

${ }^{3}$ Goodwill has been defined as "the probability that the old customers will resort to the old place." Cruttwell v. Lye, 17 Ves. 335, 346 (Ch., 1810) ; see Byrne v. Barrett, 268 N.X. 199, 206, 197 N.E. 217, 218 (1935).

'See pp. 286-87 infra.

52 Esp. 732, 734 (N.P., 1799).

' 306 N.Y. 172, 117 N.E. 2d 237 (1954).

${ }^{7}$ Ibid., at 181, 241. 
On July 3 , the Scheideler group met with Mr. Jones to discuss the possibility of purchasing the firm. They told him that the "agency's customers had already been 'presold' on the alternative plan," and that Jones could sell or the group would "resign en masse within 48 hours." Negotiations collapsed on August 6, and on the following day six of the group resigned as officers and directors, though they continued as employees. On the same day, the Manhattan Soap Co., whose annual billings averaged from three to four million dollars, informed the firm that its account would be removed by September 30. On August 22, a new firm was incorporated and started operations on September 10, 1951. During the weeks from the middle of August to mid-September, nine accounts terminated their relationships with the Duane Jones Co. and went to the new firm; and during the same period all but one of the subsequent defendants left to join it. ${ }^{10}$ By the beginning of November the new firm had seventy-one out of one hundred thirty-two persons formerly employed by the Duane Jones Co., including officers and top account executives-many of the latter organization's "key men."11

The Duane Jones Co. sued to recover the lost profits resulting from the appropriation of $\$ 4,500,000$ of annual billings and about half its employees. Neither the personnel nor the accounts had been under contract. The New York Court of Appeals unanimously affirmed plaintiff's $\$ 300,000$ award, holding that the defendants, while still employed, had

determined upon a course of conduct which, when subsequently carried out, resulted in benefit to themselves through destruction of plaintiff's business, in violation of the fiduciary duties of good faith and fair dealing imposed on defendants by their close relationship with plaintiff corporation. ...

Nor is it a defense to say the defendants ... . did not avail themselves of the benefit of the customers and personnel diverted from plaintiff until after defendants had received notice of discharge or had informed plaintiff of their intention to leave Duane Jones Company. Upon the record the jury might have found that the conspiracy originated in June or July while a fiduciary duty existed, and that the benefits realized ... in September were merely the result of a predetermined course of action. ${ }^{\mathbf{1 2}}$

Further,

[T]he accounts and personnel were acquired through solicitation by, or at the direction of, the individual defendants prior to or during the period when they were completing their duties as employees of plaintiff; and ... the rival agency was formed and the accounts and personnel were solicited without disclosure of such activities to plaintif. ${ }^{13}$ (Emphasis supplied.)

${ }^{\circ}$ Ibid.

${ }^{10}$ Defendant Robert Hayes resigned and became associated with a competing firmnot the firm formed from Duane Jones Co. He was nonetheless held liable as a conspirator.

21 306 N.Y. 172, 184, 117 N.E. 2d 237, 243 (1954).

12 Ibid., at 189, 245-46.

${ }^{23}$ Ibid., at 188, 245. 
The clearest analysis of the appropriation problem appears in cases involving partnerships. In contrast, a consistent theory concerning attempted appropriations by employees or officers has not been articulated.

The partnership cases have been rationalized in terms of "equal opportunity"14 or its converse, "undue advantage."15 An "equal opportunity" is afforded if the other partners know that an appropriation may be attempted and have a reasonably equivalent opportunity to procure the expectancy. ${ }^{16}$ To avoid liability, the appropriator must give his partners actual or "constructive" notice of his plans. Apparently, if explicit notice of the proposed appropriation is not given, the situation must be such that a reasonably prudent businessman would recognize that the organization is disintegrating, and that he should look toward the problem of retaining the firm's intangible assets. Even though the relationship may be terminated at any time, that fact alone is not notice of attempted appropriation. ${ }^{17}$ Furthermore, the mere fact that an expiration date has been included in the partnership agreement, and it is approaching, does not give one partner license to appropriate expectancies without notice to the others..$^{18}$ On the other hand, should a partner notify his copartners that he is withdrawing from the compact and then steps are taken looking toward dissolution, there may be implied notice of the planned appropriation. ${ }^{19}$ In one situation, it has been held that no notice is necessary. If both parties attempt to procure the expectancy independently, the loser will not be heard to complain that he did not know that his partner was also attempting to appropriate. ${ }^{20}$

The second requirement, an opportunity to compete on reasonably equal terms, has appeared only in cases involving extreme variations in bargaining

It E.g., Meinhard v. Salmon, 249 N.Y. 458, 465, 164 N.E. 545, 547 (1928); Holmes v. Darling, 213 Mass. 303, 305, 100 N.E. 611, 612 (1913).

${ }^{15}$ E.g., Holmes v. Darling, 213 Mass. 303, 304, 100 N.E. 611, 612 (1913); Tygart v. Wilson, 39 App. Div. 58, 63, 56 N.Y.S. 827, 830 (3d Dep't, 1889); Mitchell v. Reed, 61 N.Y. 123, 133 (1874).

${ }^{16}$ E.g., Tygart v. Wilson, 39 App. Div. 58, 56 N.Y.S. 827 (3d Dep't, 1889).

${ }^{17}$ Ambler v. Whipple, 20 Wall. (U.S.) 546 (1874) ; cf. Sohon System, Inc. v. Troub, 252 App. Div. 553, 300 N.Y.S. 438 (1st Dep't, 1937).

${ }^{28}$ Mitchell v. Reed, 61 N.Y. 123 (1874); Meinhard v. Salmon, 249 N.Y. 458, 164 N.E. 545 (1928); cf. Holmes v. Darling, 213 Mass. 303, 100 N.E. 611 (1913). But cf. Jones v. Cadenas, 200 App. Div. 635, 193 N.Y.S. 513 (1st Dep't, 1922).

${ }^{10}$ E.g., Meyer v. Sharp, 341 Ill. App. 431, 94 N.E. $2 d 510$ (1950); Thursby v. Kirby, 171 Misc. 310, 12 N.Y.S. 2d 279 (Special Term, 1939) ; Bayer v. Bayer, 215 App. Div. 454, 214 N.Y.S. 322 (1st Dep't, 1926). In some cases mere notice of termination has been held sufficient. Tygart v. Wilson, 39 App. Div. 58, 56 N.Y.S. 827 (3d Dep't, 1889); cf. Washer v. Seager, 272 App. Div. 297, 71 N.Y.S. $2 d 46$ (1st Dep't, 1947), aff'd 297 N.Y. 918,79 N.E. $2 d 745$ (1948).

${ }^{20}$ See Lindsay v. Swift, 230 Mass. 407,119 N.E. 787 (1918). 
power. ${ }^{21}$ The courts in such situations have tended to require explicit communication of the intent to perform specific acts, ${ }^{22}$ and one case has disallowed an appropriation although adequate notice was given because of the grossly disproportionate bargaining power. ${ }^{23}$

Analysis in the employee cases has been neither clear-cut nor consistent, in part because of a tendency to overemphasize the element of "secrecy."24 "Secrecy" appears to imply to many courts unfair or fraudulent behavior, and liability is imposed on that basis alone. Some courts, however, have placed this element in a context of "equal opportunity," requiring only that an employee somehow disclose his intentions so as to give the employer a chance to "compete on equal terms." 25

Many acts prior to the termination of employment may be classified as "preparation," not "appropriation," and are permitted regardless of the manner of performance. ${ }^{26}$ Thus, secrecy is immaterial where only the machinery for a future appropriation is created-where, for example, the employee purchases the business, stock, and goodwill of a competitor. ${ }^{27}$

The Restatement of Agency declares that, prior to the termination of the agency, the employee may "make arrangements" to compete with his principal but he cannot "solicit customers" or "do other similar acts in direct

${ }^{21}$ See note 44 infra.

${ }^{2}$ Sorenson v. Nielson, 240 N.Y.S. 250 (Special Term, 1930) ; Williamson v. Monroe, 101 Fed. 322 (W.D. Ark., 1900).

${ }^{23}$ Clegg v. Edmondson, 8 De G. M. \& G. 787 (1857). In addition, an employee is not allowed to appropriate the benefits from the particular duty for which he has been employed, terminating his relationship for this purpose. Frank Sheridan Jonas, Inc. v. Romanat, 94 N.Y.S. 2d 727 (1950), aff'd 278 App. Div. 809, 104 N.Y.S. 2d 457 (1st Dep't, 1951); Connelly v. Special Road \& Bridge Dist. No. 5, 99 Fla. 456, 126 So. 794 (1930); Trice v. Comstock, 121 Fed. 620 (C.A. 8th, 1903).

24 E.g., see Horn Pond Ice Co. v. Pearson, 267 Mass. 256, 166 N.E. 640 (1929).

${ }^{25}$ Frank Sheridan Jonas, Inc. v. Romanat, 94 N.Y.S. $2 d$ 727, 731 (1950), aff'd 278 App. Div. 809, 104 N.Y.S. 2d 457 (1st Dep't, 1951) ; Byrne v. Barrett, 268 N.Y. 199, 207, 197 N.E. 217,219 (1935). Cf. Lindsay v. Swift, 230 Mass. 407, 119 N.E. 787 (1918). See Glasser v. Essaness Theatres Corp., 414 Mll. 180, 111 N.E. 2d 124 (1953); Colonell v. Goodman, 78 F. Supp. 845 (E.D. Pa., 1948), aff'd 169 F. 2d 275 (C.A. 3d, 1948); Connelly v. Special Road \& Bridge Dist. No. 5, 99 Fla. 456, 126 So. 794 (1930).

${ }^{26}$ In order that employee activity may be considered preparation for competition, he must expect to sever his relationship and the expectation must be realized within a reasonable time. Colonell v. Goodman, 78 F. Supp. 845 (E.D. Pa., 1948), aff'd 169 F. 2d 275 (C.A. 3d, 1948).

${ }^{27}$ Greenburg v. S. D. Childs \& Co., 147 Ill. App. 477 (1909), aff'd 242 Ill. 110, 89 N.E. 679 (1909). He may organize a new business, Levy v. Jarrett, 198 S.W. 333 (Tex. Civ. App., 1917) ; Myers v. Roger J. Sullivan Co., 166 Mich. 193, 131 N.W. 521 (1911); or even contract to operate in competition with the employer on the condition of obtaining one of the employer's suppliers, Lindsay v. Swift, 230 Mass. 407, 119 N.E. 787 (1918). 
competition with the employer's business."2s "Solicitation" has been defined as asking "with earnestness to endeavor to obtain, or to invite . . . [by] personal petition and importunity addressed to a particular individual. . . ."20 Active solicitation is an appropriation even though the contract or request for assurances is to become effective only after the termination of the agency. ${ }^{30}$

The courts have held that the mere communication to the employer's customers of the termination of employment or of the servant's availability for future services is not an appropriation. ${ }^{31}$ Notification to clients that the employee will call upon them for his own account in the future is also permitted. ${ }^{32}$ Some courts have even allowed an employee to make a reasonable request for business to commence at the conclusion of the employment, or to state a willingness to discuss business upon the invitation of the customer. ${ }^{33}$

An employee often wishes to take associates with him on the new venture in competition with the employer. The planned withdrawal of several employees to enter into competition with the employer usually is not considered a conspiracy. ${ }^{34}$

[There can be no doubt that] the defendants were free to leave the employ of plaintiff and engage in a similar business. . . For men to agree and plan to enter business as associates, even though they have a design to draw their patronage from many rivals, or all that a particular rival may have, does not constitute them conspirators. ${ }^{35}$

The Restatement suggests, however, that if a manager secretly concludes contracts with his employer's most essential servants by which they agree to work for him in a competing business he may be committing an actionable breach of loyalty to the employer. ${ }^{36}$

${ }^{23}$ Rest., Agency \& 393, Comment e (1933).

20 Aetna Bldg. Maintenance Co. v. West, 39 Calif. 2d 198, 203, 246 P. 2d 11, 15 (1952).

${ }^{30}$ E.g., Connelly v. Special Road \& Bridge Dist. No. 5, 99 Fla. 456, 126 So. 794 (1930); Colonial Laundries, Inc. v. Henry, 48 R.I. 332, 138 Atl. 47 (1927).

${ }^{31}$ Aetna Bldg. Maintenance Co.v. West, 39 Calif. 2d 198, 246 P. 2 d 11 (1952) ; Continental Car-Na-Var Corp. v. Moseley, 24 Calif. 2d 104, 148 P. 2d 9 (1944); Nichol v. Martyn, 2 Esp. 732 (N.P., 1799).

${ }^{32}$ Witmer v. Arkansas Dailies, Inc., 202 Ark. 470, 151 S.W. 2d 971 (1941).

${ }^{33}$ Aetna Bldg. Maintenance Co. v. West, 39 Calif. 2d 198, 246 P. $2 d 11$ (1952); Nichol v. Martyn, 2 Esp. 732 (N.P., 1799); cf. Dondero v. Standard Emblem Co., 45 R.I. 329, 121 Atl. 401 (1923).

34 Continental Car-Na-Var v. Moseley, 24 Calif. 2d 104, 148 P. 2 d 9 (1944); General Bronze Corp. v. Cupples Products Corp., 99 F. Supp. 924 (E.D. Mo., 1950). But cf. Duane Jones Co. v. Burke, 306 N.Y. 172, 117 N.E. 2d 237 (1954).

${ }^{25}$ Fidelity Appraisal Co. v. Federal Appraisal Co., 217 Calif. 307, 314, 18 P. 2d 950, 953 (1933).

${ }^{36}$ Rest., Agency $\S 393$, Comment e (1933). The Jones case may be explained by this "key-man" rule. It appears, however, that courts have confused this rule with notions of conspiracy. By labeling an act a "conspiracy" rather than a "breach of duty," a whole group, rather than its organizer, may be subject to liability. These two legal labels are not interchangeable. 
III

In discussing the appropriation problem, the courts have paid lip service to a distinction between the employment relationship and relationships arising from other forms of business organization. ${ }^{37}$ The distinction, however, has not prevented indiscriminate citation of partnership cases as authority for propositions concerning employment relationships. ${ }^{38}$ Yet the analysis of partnership cases has not been adopted in employee decisions; the latter have been clouded by discussions of the advantages of the free enterprise system ${ }^{30}$ or the untoward injury to the employer. ${ }^{40}$ The courts have tended to apply personal ideals of fairness and to rationalize results by applying such amorphous concepts as "breach of duty," "intent to injure,"42 or "conversion of confidential information." 43

The differences in the forms of business organization do not offer a sound basis for distinguishing between the partnership appropriation problem and the same problem in an employment context. ${ }^{44}$ The appropriation problem reflects a conflict in broad underlying policies which obliterates any possible differences resulting from the varying types of business units. It thus appears proper that courts have not emphasized these differences as a basis for applying varying rules.

When the "equal opportunity" or "undue advantage" analysis is applied to a set of facts, three variables appear to be important: (1) notice; (2) bargaining power of the appropriator; and (3) the actual and continuing presence of an expectancy. The first two have been explicitly discussed in the partnership cases; the final one appears to be implicit in numerous decisions. The Duane Jones case, when evaluated in these terms, seems difficult to justify.

(1) It is questionable whether the Duane Jones case can stand on lack of notice. The court's finding that Mr. Jones had not been notified of the

\footnotetext{
${ }^{37}$ E.g., see Commonwealth Sanitation Co. of N.Y. v. Fox, 107 N.Y.S. 2d 935, 938 (S. Ct., 1951) ; Meinhard v. Salmon, 249 N.Y. 458, 463-64, 164 N.E. 545, 546 (1928).

${ }^{38}$ E.g., see Duane Jones Co. v. Burke, 306 N.Y. 172, 189, 117 N.E. 2d 237, 245 (1954); Byrne v. Barrett, 268 N.Y. 199, 197 N.E. 217 (1935). In Eberle \& Co. v. Morgensteen, 6 La. App. 35 (1927), a personal service corporation appears to be treated as a partnership.

${ }^{30}$ E.g., New Rochelle Coal \& Lumber Co. v. Pugliese, 86 N.Y.S. 2d 757 (S. Ct., 1949).

${ }^{10}$ E.g., Colonial Laundries, Inc. v. Henry, 48 R.I. 332, 138 Atl. 47 (1927).

${ }^{4}$ E.g., Trice v. Comstock, 121 Fed. 620 (C.A. 8th, 1903).

2 E.g., Gloria Ice Cream \& Milk Co. v. Cowan, 2 Calif. 2d 460, 41 P. 2d 340 (1935).

${ }^{43}$ E.g., Forn Pond Ice Co. v. Pearson, 267 Mass. 256, 166 N.E. 640 (1929).

"In both the partnership and employee cases, the duty and activity of the alleged appropriator may be viewed in the light of his bargaining power in relation to the expectancy. An insurance salesman has intimate contact with his clients, Scott \& Co. v. Scott, 186 App. Div. 518, 174 N.Y.S. 583 (1st Dep't, 1919), as has a managing partner with the business associates, Young v. Cooper, 30 Tenn. App. 55, 203 S.W. $2 \mathrm{~d} 376$ (1947). In such situations the relatively inactive individual, whether a managing partner or an employer, may be at a serious disadvantage in competing for business.
} 
defendants' intentions to solicit customers until after the solicitation had been successful is not helpful, since knowledge of specific acts is unnecessary. Mr. Jones had been informed of the clients' approval of defendants' plans two weeks after the initial meeting of the defendants, and the ultimatum appears clearly to satisfy the requirements for implied notice. It should be noted that defendants' firm was established nearly two months after the ultimatum was delivered, and the solicitation apparently continued for at least another six weeks, since the fifty per cent appropriation was computed at the end of that period. Possibly the activities of the defendants, during the two-week period before the ultimatum, were appropriations, though it appears equally likely that the defendants were, in the words of the Restatement, "making arrangements" not amounting to a "solicitation."

(2) Perhaps the strongest argument for the plaintiff results from the bargaining position of the "key men" who had banded together. As an advertising firm, plaintiff offered personalized service, and the caliber and harmony of its personnel provided the assurance of its future business. The clients had extensive dealings with the employees of the Duane Jones Co. and trusted them. As compared to Mr. Jones, the defendants might have had disproportionate bargaining power. ${ }^{45}$ Another factor, however, must be considered before liability in the Duane Jones case can be determined.

(3) It is elementary that the employer must have the expectancy before he may complain of its conversion. If there is no expectancy, there can be no liability for its appropriation. For instance, if a supplier indicates he will deal only with a single individual, no one else may claim an expectancy of future dealings with him. ${ }^{46}$ Also, one may alienate an expectancy by indiscreet behavior, and another is then free to appropriate. ${ }^{47}$

Clearly, the person claiming the injury must not have been the cause for the termination of the expectancy. ${ }^{48}$ In the Duane Jones case the indiscretions of Mr. Jones could well have destroyed many of the firm's expectancies. A number of factors point to this conclusion. The Manhattan Soap Co., which was held not to be a party to the conspiracy, notified plaintiff it planned to terminate its account long before the formation of defendants' new business. The extreme dissatisfaction of other clients was indicated by the large loss of billings prior to defendants' actions, and it seems reasonable

\footnotetext{
${ }^{25}$ See note 44 supra. Several cases illustrate the use by employees in particularly strong bargaining positions of threats of competition to obtain employment concessions. While the court may attach little significance to them, Witmer v. Arkansas Dailies, Inc., 202 Ark. 470, 151 S.W. 2d 971 (1941), they may be held to indicate "intent to injure." See Gloria Ice Cream \& Milk Co. v. Cowan, 2 Calif. 2d 460, 41 P. 2d 340 (1935).

'Washer v. Seager, 272 App. Div. 297, 71 N.Y.S. 2d 46 (1st Dep't, 1947), aff'd 297 N.Y. 918, 79 N.E. 2d 745 (1948); Crittenden \& Cowler Co. v. Cowler, 66 App. Div. 95, 72 N.Y.S. 701 (3d Dep't, 1901).

${ }^{67}$ Tygart v. Wilson, 39 App. Div. 58, 56 N.Y.S. 827 (3d Dep't, 1899).

${ }^{4}$ See Glasser v. Essaness Theatres Corp., 414 III. 180, 111 N.E. 2d 124 (1953); Williamson v. Monroe, 101 Fed. 322 (W.D. Ark., 1900).
} 
to believe that more accounts would have broken off their relations with plaintiff even if the defendants had not organized a competing business. Even if it were agreed that liability was properly imposed in the Duane Jones case, it seems clear that the court's measure of damages was improper. The court of appeals argued that a $\$ 300,000$ verdict was reasonable, since it was based on the proposed purchase price to be paid Mr. Jones for the business. Of course, this was based on $\$ 9,000,000$ of billings, and assumed that the defendants would operate the business and that Mr. Jones would resign. Such assumptions should not have entered into the measure of damages. The correct measure is the difference between the present value of the business and the value it would have had if the defendants had not wrongfully appropriated a part of it. The defendants should not have been made to pay for business which would be lost to the firm if Mr. Jones continued as its owner, but which could have been retrieved if the defendants bought the corporation..$^{40}$

\section{IV}

The rule governing the permissible limits to pre-termination solicitation should be formulated so as to combine easy predictability of result, freedom of individual movement within the economy, and protection of legitimate business interests. To formulate a rule which strikes a satisfactory balance among these requirements, it is first necessary to take a brief look at the alternatives available to the employee.

The obvious alternative to solicitation prior to the termination of employment is solicitation subsequent thereto. Solicitation after employment is generally permitted ${ }^{50}$ in the absence of a unique list of customers. ${ }^{51}$ The

${ }^{4}$ Perhaps an additional factor to weigh, although one which is debatable in theory, is the size of the appropriation. But whether logical or not, large appropriations, like that of the Duane Jones case, cause courts to argue that the defendants should have bought the business, not appropriated it. Small appropriations are more easily dismissed as part of the workings of the competitive system. Where the injury to the employer is not substantial, suit is not likely to be brought. For a case very similar to the Jones case on its facts, but holding the acts did not violate the employee's "duty," see Witmer v. Arkansas Dailies, Inc., 202 Ark. 470, 151 S.W. 2d 971 (1941).

${ }^{50}$ The courts have had no difficulty in finding policy reasons favoring post-employment solicitations: "It would abridge competition in business, the life of trade, if an employee who had rendered services to a business of any character for a long period of time and who had helped build up a business on account of performing his duties well, should be prohibited after severing his relationship with a business concern, from establishing and prosecuting a similar business in the same territory or field in which his employer had done business, especially where the employee had not contracted when entering into the employment to refrain from establishing an independent business of like nature. Legitimate competition should be encouraged rather than restricted, and in the aid of the freedom of employment, combinations and monopolies which would result in the restraint of trade should not be tolerated in a democratic form of government." Witmer v. Arkansas Dailies, Inc., 202 Ark. 470, 476, 151 S.W. 2d 971, 973-74 (1941).

5 Boosing v. Dorman, 148 App. Div. 824, 133 N.Y.S. 910 (4th Dep't, 1912); Rest., Agency § 396, Comments a, b (1933). Consult note, 9 B.U.L. Rev. 259 (1929). 
trust and confidence of the customers in the employee may be exploited by him after he enters into competition with his former employer. ${ }^{52}$ Certain cases involving merchandising firms, however, have imposed liability for post-employment solicitation by emphasizing the cost to the employer of assembling a group of customers; the necessity of goodwill for the continuation of his business; and the fact that the employer provided the opportunity which enabled the employees to "ingratiate themselves with a specific group of people gathered into a single unit by the employer." ${ }^{253}$ While this exception might appear applicable to the Duane Jones case, the courts have distinguished situations where the products are necessarily dissimilar (as in the advertising field) or where there is little probability of repeat business. ${ }^{54}$

Though the employee may encounter less risk of liability in soliciting subsequent to his employment, other factors operate to make this alternative unattractive. The employee will prefer to draw wages while organizing a new business. Further, the employee, finding his plan unwise because of lack of customer participation, may wish to return to his old position; this may be difficult if he has already terminated employment.

In devising a rule, consideration should also be given to covenants not to enter competition after termination of employment. Such covenants have been upheld if limited to a reasonable area and time ${ }^{55}$ and, theoretically at least, are supposed also to be limited to the employee's use of information and knowledge gained while in the employer's trade by reason of his employment. $^{56}$ It may be suggested that such covenants are undesirable; that a better way to prevent future competition is to attempt to deter the employee from terminating employment by paying him an attractive salary commensurate with his ability and worth while a part of the firm.

Whatever the merits of a rigid rule as to what may and may not be done prior to termination of employment, surely something better than the present confusing doctrines of the employee cases can be found. ${ }^{57}$ One possible rule would prohibit solicitation until after the employment has been terminated. The lines of battle would then be drawn, and all would have an opportunity to obtain the favor of the customer. ${ }^{58}$ But the adoption of such a rule would

${ }^{52}$ Morrison v. Phillips, 147 Misc. 238, 263 N.Y.S. 816 (S. Ct., 1933) ; H. W. Gossard Co. v. Crosby, 132 Iowa 155, 109 N.W. 483 (1906). Consult Hannigan, The Implied Obligation of an Employee, 77 U. of Pa. L. Rev. 970 (1929).

s Colonial Laundries, Inc. v. Henry, 48 R.I. 332, 337, 138 Atl. 47, 49 (1927).

ss Ibid.

${ }^{\star}$ See, generally, Cowan, Covenants Not To Compete after Termination of Employment, 5 Peabody L. Rev. 79 (1941).

so Ibid., at 82.

s7 "Exact legal classifications are not always adequate in determining the boundaries of fairness and loyalty." Byrne v. Barrett, 268 N.Y. 199, 206-7, 197 N.E. 217, 218 (1935).

Consult Sharp and Fox, Business Ethics, 226-28 (1937). 
make employees less anxious to trade the security of employment for unknown entrepreneurial risks, and therefore seems undesirable. ${ }^{59}$

A better rule would require the employee merely to give a general notice to the employer before any action could be taken in relation to the master's expectancies. But to ask an employee to divulge his entire plan to the employer to protect the employer's interests would be going too far toward the inhibition of freedom of action. All that should be required is notice which, by a standard of "commercial reasonableness," should forewarn the employer. It may be that mere notice of termination of employment should be held sufficient.

In any case, it would be beneficial if the courts would make explicit their criteria of liability. The present uncertainty has probably increased the risks involved in litigation so as to deter many employers from suing to recover unjustified appropriations. The actions of the employee probably have not been greatly affected, and it may even be that he has been favored by the uncertainty. The somewhat harsh decision in the Duane Jones case may offset this employee advantage by encouraging more employers to litigate. ${ }^{60}$ In turn, the additional litigation may well force a judicial delineation of the latitude given to employees in preparing to compete which is more reasonable than the latitude permitted in the Duane Jones case.

50 "One is entitled to seek other employment before he is on the street. The contrary would be a monstrous doctrine." Meyers v. Roger J. Sullivan Co., 166 Mich. 193, 197, 131 N.W. 521, 523 (1911).

${ }^{\infty}$ What the Jones Decision Means, Advertising Age p. 1A, col. 2 (January 11, 1954). 